\title{
Peningkatan Hasil Belajar Fisika Dengan Metode Pembelajaran Brainstorming
}

\author{
Ika Vidiasari Aristawati \\ aqilaathaya2013@gmail.com \\ SMKN 1 Trenggalek
}

\begin{abstract}
Classroom Action research is against the background of the lack of activeness of the students, especially class X TKRO 01 SMK Negeri 1 Trenggalek school year 2018/2019 in the scientific attitude and mastery learning classical low. Based on the acquisition of the data, the percentage of student activity $42,86 \%$. Because it then affects the learning outcomes of students who tend to be low around $54,29 \%$ of the expected result or the limit of the minimum standard of completeness. It is based on obtaining the results of the study on previous material. This research method used the research model to adapt the combined Sanford and Kemmis using classroom action research. The study was conducted in two cycles: one cycle is performed as much as two times the action research. The subject of research is class X TKRO 01 as many as 35 students. Data collection techniques in this research using observation and test. Data in the form of learning outcomes in the form of assessment of the third aspect, among others, attitude, skills, knowledge with the use of instruments as appropriate. The results of the test in cycle I based on the data acquisition of the percentage of mastery learning classical reached $74,29 \%$ with the average results of the acquisition value 71,81 . The percentage of mastery the standards mastery minimum in the classical style. While for the assessment of the activity, the percentage of active students in scientific attitude to achieve $71,43 \%$ with the number of students active in 25 of the 35 students. Assessment of skills to achieve the percentage of $71,43 \%$ with the average value of the skills of 63,81 . The results of the test in cycle II data based on the acquisition of the percentage of mastery learning classical reached $85,71 \%$ with the average results of the acquisition value 76,00 . While for the assessment of the activity, the percentage of active students in scientific attitude reached $85,71 \%$ with the number of students active 30 of 35 students and assessment of skills to achieve the percentage of $82,86 \%$ with the average value of the skills of 77,14 . Based on the acquisition of a percentage of the value of the learning result from cycle I and cycle II increased by $11,42 \%$ to the value of knowledge, while the liveliness of the students in the scientific attitude increased by $11,43 \%$, while the skills of students increased by $14,28 \%$, so learning the methods of brainstorming can improve student learning outcomes.
\end{abstract}

Keywords: brainstorming, learning outcome, physics

Abstrak
Penelitian Tindakan Kelas ini dilatar belakangi kurangnya keaktifan siswa terutama
kelas X TKRO 01 SMK Negeri 1 Trenggalek tahun pelajaran 2018/2019 dalam
bersikap ilmiah dan ketuntasan belajar klasikal yang rendah. Berdasarkan
perolehan data prosentase keaktifan siswa sebesar 42,86\%. Karena hal tersebut
maka mempengaruhi hasil belajar siswa yang cenderung rendah sekitar $54,29 \%$
dari hasil yang diharapkan atau batas standar minimum ketuntasan. Hal tersebut
didasarkan dari perolehan hasil belajar pada materi sebelumnya. Penelitian ini
menggunakan metode penelitian tindakan kelas menggunakan model penelitian
adaptasi dari gabungan Sanford dan Kemmis. Penelitian dilakukan dalam dua


siklus, satu siklus dilaksanakan sebanyak dua kali tindakan penelitian. Subjek penelitian adalah kelas X TKRO 01 sebanyak 35 siswa.Teknik pengumpulan data pada penelitian ini menggunakan hasil observasi dan tes tulis. Data berupa hasil belajar dalam bentuk penilaian ketiga aspek antara lain sikap, keterampilan dan pengetahuan dengan menggunakan instrumen tes dan rubrik pengamatan. Hasil tes pada siklus I berdasarkan data perolehan prosentase ketuntasan belajar secara klasikal mencapai $74,29 \%$ dengan rata-rata hasil perolehan nilai 71,81 . Prosentase ketuntasan tersebut masih di bawah standar ketuntasan minimun secara klasikal. Sedangkan untuk penilaian keaktifan, prosentase keaktifan siswa dalam bersikap ilmiah mencapai $71,43 \%$ dengan jumlah siswa aktif 25 dari 35 siswa. Penilaian keterampilan mencapai prosentase $71,43 \%$ dengan nilai rata-rata keterampilan sebesar 63,81 . Hasil tes pada siklus II berdasarkan data perolehan prosentase ketuntasan belajar secara klasikal mencapai $85,71 \%$ dengan ratarata hasil perolehan nilai 76,00 . Sedangkan untuk penilaian keaktifan, prosentase keaktifan siswa dalam bersikap ilmiah mencapai $85,71 \%$ dengan jumlah siswa aktif 30 dari 35 siswa dan penilaian keterampilan mencapai prosentase $82,86 \%$ dengan nilai rata-rata keterampilan sebesar 77,14 . Berdasarkan perolehan prosentase nilai hasil belajar dari siklus I dan siklus II mengalami peningkatan sebesar $11,42 \%$ untuk nilai pengetahuan, sedangkan keaktifan siswa dalam bersikap ilmiah meningkat sebesar $11,43 \%$, sedangkan keterampilan siswa meningkat sebesar $14,28 \%$ sehingga pembelajaran dengan metode brainstroming dapat meningkatkan hasil belajar siswa.

Kata kunci: brainstorming, hasil belajar, fisika.

\section{PENDAHULUAN}

Konsep pembelajaran fisika menuntut aspek pengetahuan, aspek sikap dan aspek keterampilan berjalan beriringan, dalam hal ini kreatifitas siswa lebih diutamakan dan ditingkatkan . Pembelajaran fisika memiliki tujuan siswa dapat memahami konsep-konsep yang ada dan mampu menggunakan metode ilmiah untuk memecahkan masalah yang dihadapi.

Berdasarkan dari observasi awal pada siswa mengenai hasil belajar masih sangat rendah, hal tersebut dengan penilaian pada segi pengetahuan dan keterampilan. Prosentase hasil belajar siswa pada segi pengetahuan sebesar siswa sebesar $54,29 \%$ sedangkan pada segi keterampilan sebesar 42,86 \% sedangkan keaktifan ilmiah sebesar 42,86 \% sehingga sangat jauh hasil yang diharapkan dari batas standar minimum $75 \%$ ketuntasan minimal.

Menurut Hamalik (2006) hasil belajar akan tercapai jika terjadi perubahan tingkah laku dari ketidak mengertian menjadi lebih tahu. Hasil belajar pada penlitian ini mengacu pada ketuntasan belajar siswa sesuai standar ketuntasan minimal yang diterapkan sekolah, selain penilaian secara pengetahuan juga keterampilan dengan keaktifan siswa dalam menyampaikan pendapat dan melakukan kegiatan presentasi. Penguasan materi yang rendah akan menyebabkan ketuntasan belajar siswa juga akan rendah. Ketika siswa kurang aktif dalam proses pembelajaran akan menghambat siswa untuk memahami konsep sehingga ketuntasan belajar juga tidak tercapai. Hasil belajar menurut penelitian dari Wardani (2016) akan terwujud jika siswa diberikan keleluasan untuk menyampaikan pemikirannya sehingga siswa akan mudah memahami konsep tersebut.

Hasil belajar siswa yang rendah pada observasi sebelumnya, guru berupaya melakukan pembenahan dalam proses pembelajaran salah satunya menggunakan metode 
pembelajaran Brainstorming. Metode pembelajaran brainstorming tidak membatasi kemampuan anak untuk berfikir kritis sehingga siswa akan lebih mudah menuangkan pemikirannya. Kelebihan dari brainstorming ide yang muncul akan lebih banyak karena tidak adanya pembatasan dan berfikir kritisnya akan meningkat. Langkah-langkah pembelajaran brainstorming pendidik memberikan permasalahan yang merangsang pemikiran, siswa diberikan keleluasan dalam berpendapat dan menuangkannya dalam peta konsep.

Melalui diskusi dengan teman guru dan mengkaji pustaka maka metode pembelajaran yang tepat dapat dijadikan solusi untuk meningkatkan hasil belajar siswa. Salah satu metode yang dapat mengatasi permasalahan tersebut yaitu metode pembelajaran Brainstorming. Menurut pendapat (Palil, 2018) Brainstorming merupakan salah satu cara yang digunakan untuk mengeluarkan ide dan dikemas secara struktur serta sistematis. Brainstorming memiliki kelebihan memunculkan banyak ide dari siswa tanpa adanya batasan serta dapat meningkatkan kemampuan berfikir kritis.

\section{METODE PENELITIAN}

Penelitian ini menggunakan metode deskriptif kualitatif dengan jenis Penelitian Tindakan Kelas (PTK). Pelaksanaan penelitian di SMK Negeri 1 Trenggalek dengan alamat Jalan Brigjen Sutran No. 03 Trenggalek. Adapun pelaksanaannya bulan September - Oktober tahun 2018. Subyek penelitian adalah siswa kelas X TKRO 01 dengan jumlah siswa 35 orang. Penelitian dilaksanakan dalam dua siklus, meliputi perencanaan, pelaksanaan tindakan, observasi, evaluasi dan refleksi (Arikunto, 2019:143. Hasil refleksi dari siklus I akan digunakan sebagai dasar dalam merencanakan tindakan pada siklus II. Menurut Taniredja dkk (2010:16) penelitian tindakan kelas mengangkat masalah - masalah yang aktual yang dilakukan oleh para guru yang merupakan percermatan kegiatan belajar yang berupa tindakan untuk memperbaiki dan meningkatkan praktik pembelajaran di kelas secara profesional.

Teknik pengumpulan data mengunakan observasi, tes dan dokumentasi. Instrumen yang digunakan dalam penelitian ini ada dua macam yaitu: (1) Instrumen Tes dengan soal tes mengenai konsep pengetahuan siswa, (2) Instrumen Non Tes dengan lembar observasi keaktifan siswa. Instrumen non tes terdiri dari pedoman penilaian pengetahuan, pedoman pengamatan/observasi, pedoman penilaian keterampilan, pedoman penilaian sikap/ skala sikap serta dokumentasi.

Teknik analisis data yang digunakan dalam penelitian ini secara deskriptif kualitatif berdasarkan observasi terhadap proses dan hasil belajar siswa. Hasil observasi dianalisis prosentase yang hasilnya dibandingkan antara siklus I dan siklus II dengan rincian: (1) data hasil pengetahuan, sikap dan keterampilan dianalisis dengan cara dicari rata-ratanya kemudian dibuat perbandingan antara siklus I dan siklus II, (2) Seluruh analisis dituangkan dalam bentuk narasi.

\section{HASIL DAN PEMBAHASAN Paparan Tentang Kondisi Awal}


Penelitian ini memilih subyek kelas X TKRO 01 semester ganjil tahun pelajaran 2018/2019 yang berjumlah 35 siswa. Berdasarkan data yang diperoleh oleh peneliti pada materi sebelumnya masih menunjukkan rendahnya nilai hasil belajar siswa dan keaktifan siswa pada pelajaran fisika. Hal tersebut terlihat pada ketuntasan belajar siswa pada bab sebelumnya sekitar 54,29\% pada ranah pengetahuan, 42,86 \% pada ranah keterampilan dan keaktifan siswa juga masih rendah sekitar $42,86 \%$.

Hal tersebut selain dengan menggunakan skoring dalam penilaian pengetahuan, keterampilan dan sikap dapat dipaparkan kondisi riil siswa pada saat proses pembelajaran berlangsung. Materi yang diberikan guru yang dijadikan bahan pra siklus yaitu materi Besaran dan Satuan. Tampak pada beberapa siswa kurang antusias dalam menerima pelajaran. Selain kurang antusias sebagian besar siswa hanya menunggu jawaban atau hasil diskusi dari beberapa siswa yang lebih awal menyelesaikan. Secara klasikal kelas tersebut belum bisa aktif dalam pembelajaran, cenderung mengobrol dengan hal- hal yang tidak ada kaitannya dengan materi pelajaran.

\section{Paparan Kegiatan dan Hasil Pelaksanaan Siklus I Tahap Perencanaan Tindakan}

Pada tahap perencanaan peneliti dan guru pengamat melakukan diskusi tentang prosedur penelitian dan langkah-langkah pelaksanaan pembelajaran dengan metodel pembelajaran Brainstorming. Persiapan yang digunakan untuk penelitian antara lain: rencana pembelajaran yang sesuai, petunjuk penyelesaian peta konsep dengan mempersiapkan masalah yang akan dibahas, lembar observasi kegiatan siswa, rubrik penilaian keterampilan dan pengetahuan.

\section{Tahap Pelaksanaan Tindakan}

Pelaksananaan tindakan penelitian dilaksanakan selama 1 bulan yaitu bulan September 2018 sesuai dengan jadwal pelajaran yang ada di X TKRO 01 pada hari Jumat jam ke 1 -3 tiap minggunya. Materi pelajaran yang dilakukan pada kegiatan tindakan adalah gerak lurus, gerak melingkar dengan kelajuan tetap atau percepatan tetap dalam kehidupan seharihari. Kemudian guru pelaksana melakukan proses pembelajaran sesuai dengan rencana pelaksanaan pembelajaran.

Pada tahap pendahuluan guru menyampaikan tujuan pembelajaran yang akan dicapai dengan mengkaitkan persoalan fisika sehari-hari. Memberikan pertanyaan pada salah satu siswa atas nama "Apa saja yang kamu ingat tentang definisi gerak" adapun jawaban "Gerak itu berpindah posisi, gerak ada perubahan kecepatan, ada perubahan waktu" Dari proses pertanyaan tersebut untuk pembuktian, guru memberikan pengarahan atau stimulus siswa untuk mengingat kembali materi yang telah mereka dapatkan pada jenjang sebelumnya.

Pada tahap pelaksanaan guru memberikan informasi dan memberikan permasalahan untuk mengajak siswa aktif serta melakukan penjelasan singkat terkait penyusunan peta konsep materi Gerak Lurus Berubah Beraturan. Siswa dibentuk dalam beberapa kelompok dengan memberikan arahan untuk membuat pertanyaan mengenai penyusunan peta konsep tersebut. Guru mengarahkan siswa untuk mendiskusikan beberapa pertanyaan tersebut 
dengan kelompok yang telah dibagi. Hal-hal yang harus didiskusikan antara lain Gerak Lurus Berubah Beraturan untuk percepatan dan perlambatan. Perwakilan kelompok menyampaikan hasil diskusi kelompoknya ke depan kelas. Salah satu siswa menyampaikan hasil diskusi akan tetapi belum terinci secara konsep, sedangkan dari kelompok 2 belum maksimal dalam penyampaian hasil diskusi karena kurang percaya diri ketika tampil di depan kelas. Penyampaian pendapat dari kelompok lainnya masih dominan diwakili oleh beberapa siswa yang aktif, sedangkan siswa yang kurang antusias dalam pembelajaran masih belum aktif dengan lembar pengamatan sikap yang masih mendapatkan skor 50.

Pada tahap penutup guru melakukan refleksi dengan kegiatan diskusi siswa pada konsep yang telah didiskusikan. Guru memberikan arahan kepada beberapa siswa yang belum ada perubahan keaktifan dari materi sebelumnya hingga Gerak Lurus berubah Beraturan. Pada akhir proses pembelajaran siswa diberikan tes formatif ke satu yang bertujuan untuk meningkatkan keberhasilan siswa selama proses pengajaran. Pada ranah pengetahuan dengan menerapkan model pembelajaran Brainstorming memperoleh hasil rata - rata 71,81 dari ketuntasan belajar dan secara klasikal mencapai 74,29\%. Pada ranah sikap ilmiah sebesar $71,43 \%$ dan ranah keterampilan $71,43 \%$.

\section{Tahap Refleksi dan Revisi Tindakan}

Pelaksanaan kegiatan belajar pada siklus I peneliti telah melaksanakan semua proses pembelajaran sesuai dengan perangkat pengajaran yang telah direncanakan, tetapi belum mencapai ketuntasan klasika. Hal tersebut berdasarkan data pengamatan selama kegiatan berlangsung siswa yang aktif dalam mengikuti proses pembelajaran sudah cukup baik. Ketuntasan belajar mencapai 74,29 \% sehingga diperlukan tindakan untuk mencapai ketuntasan belajar secara klasikal. Sedangkan Indikator keaktifan siswa bersikap ilmiah sebesar $71,43 \%$ sedangkan keterampilan siswa sebesar $71,43 \%$ sehingga untuk meningkatkan keaktifan siswa.diperlukan perbaikan pada siklus II.

\section{Paparan Kegiatan dan Hasil Pelaksanaan Siklus I Tahap Perencanaan Tindakan}

Pada tahap perencanaan peneliti dan guru pengamat melakukan diskusi tentang refleksi dari pelaksanaan tindakan pada siklus I, melakukan perbaikan prosedur penelitian dan langkah - langkah pembelajaran dengan metode pembelajaran Brainstorming.

\section{Tahap Pelaksanaan Tindakan}

Pelaksananaan tindakan penelitian dilaksanakan selama 1 bulan yaitu bulan Oktober 2018 sesuai dengan jadwal pelajaran yang ada di X TKRO 01 pada hari Jumat jam ke 1 -3 tiap minggunya. Pada tahap pendahuluan guru menyampaikan tujuan pembelajaran dengan mengkaitkan persoalan fisika sehari-hari. Memberikan pertanyaan pada salah satu siswa "Mengapa benda jika mencapai ketinggian tertentu akan jatuh ke bawah?" adapun jawaban dari siswa tersebut "Karena benda tersebut mencapai tinggi maksimal akan berhenti dan akan jatuh". Dari proses pertanyaan tersebut untuk pembuktian, guru mengajak siswa untuk melakukan analisa berfikir dan mencari informasi terkait gerak vertikal. Guru memberikan uraian 
singkat mengenai konsep Gerak vertikal. Berdasarkan uraian tersebut siswa menyelesaikan pembuatan peta konsep terkait Gerak Vertikal.

Pada tahap pelaksanaan guru mengarahkan siswa untuk menyelesaikan peta konsep mengenai gerak vertikal sesuai dengan petunjuk yang telah disediakan. Keaktifan siswa sudah mulai nampak, terdapat kenaikan nilai sikap mengenai keaktifan siswa dari siklus I ke Siklus II. Siswa tersebut cenderung pasif ketika harus berdiskusi tanpa melakukan aktivitas. Sedangkan pada siklus ke II diharapkan siswa melakukan aktivitas penyelesaian peta konsep dengan membuat banyak cabang dari konsep utama gerak vertikal sehingga penjelasan mengenai konsep gerak vertikal akan semakin luas.

Pada kegiatan diskusi kelompok nampak siswa aktif melakukan diskusi dengan temannya jika dalam penyusunan konsepnya dirasakan belum memenuhi sesuai dengan petunjuk guru. Pada peta konsep tersebut juga diberikan contoh soal dan pembasannya yang merupakan percabangan dari rumus atau persamaan gerak vertikal.

Perwakilan kelompok menyampaikan hasil diskusi kelompoknya ke depan kelas dan sudah mulai tampak siswa yang kurang percaya diri menyampaikan hasil diskusi pada siklus I sudah mulai percaya diri dengan cara penyampaian yang lebih rinci. Penyampaian pendapat dari kelompok lainnya sudah merata untuk hampir semua kelompok

Pada kegiatan penutup guru melakukan refleksi dengan kegiatan diskusi yang telah dilaksanakan oleh siswa. Guru memberikan arahan kepada beberapa siswa yang belum ada perubahan keaktifan dan memberikan apresiasi yang baik untuk siswa yang telah berubah menjadi aktif. Pada akhir proses pembelajaran siswa diberikan tes formatif ke satu yang bertujuan untuk meningkatkan keberhasilan siswa selama proses pengajaran.

Pelaksana tindakan siklus II peneliti telah melaksanakan semua proses pembelajaran sesuai dengan perangkat pengajaran yang telah direncanakan sebelumnya. Adapun hasil yang diperoleh mengalami peningkatan dari siklus I, hal tersebut nampak pada pengamatan hasil belajar siswa pada siklus sudah mencapai ketuntasan secara klasikal. Ketuntasan belajar mencapai $85,71 \%$ sehingga tindakan yang diberikan guru telah mampu meningkatkan ketuntasan secara klasikal. Adapun Indikator keaktifan siswa dalam bersikap ilmiah sebesar $85,71 \%$ dengan ssiwa aktif 30 dari 35 siswa sehingga model pembelajaran yang telah dilaksanakan dalam penelitian mampu meningkatkan keaktifan siswa dalam pembelajaran. Sedangkan keterampilan siswa dalam pembelajaran prosentasenya mencapai 82,86 \%.

\section{Paparan Perbandingan Hasil Siklus I dan Hasil Siklus II}

Penelitian dengan menggunakan metode pembelajaran peta konsep semester 1 pada kelas X TKRO 01 dimulai dengan menganalisa kondisi awal siswa dan mempersiapkan instrumen dalam penelitian. Pelaksanaan siklus I mengacu pada rencana pelaksanaan pengajaran dengan siswa diarahkan untuk mencari konsep mengenai Gerak Lurus Berubah Beraturan. Hasil tes pada siklus I berdasarkan data perolehan prosentase ketuntasan belajar klasikal mencapai $74,29 \%$ dengan rata-rata hasil perolehan nilai 71,81. Prosentase ketuntasan tersebut masih di bawah standar ketuntasan minimun secara klasikal. Sedangkan untuk penilaian keaktifan, prosentase keaktifan siswa dalam bersikap ilmiah mencapai 71,43 \% 
dengan jumlah siswa aktif 25 dari 35 siswa. Penilaian keterampilan mencapai prosentase $71,43 \%$ dengan nilai rata-rata ketrampilan sebesar 63,81.

Peneliti melakukan evaluasi dan refleksi dari siklus I yang belum mencapai tingkat ketuntasan minimum dan keaktifan siswa yang masih dibawah $75 \%$ maka diperlukan perbaikan tindakan pada siklus II.

Siklus II dilaksanakan berdasarkan evaluasi dan refleksi dari siklus I dengan memperbaiki rencana pelaksanaan pengajaran dan instrumen yang disesuaikan. Hasil tes pada siklus II berdasarkan data perolehan prosentase ketuntasan belajar secara klasikal mencapai $85,71 \%$ dengan rata-rata hasil perolehan nilai 76,00 . Prosentase ketuntasan sudah memenuhi standar ketuntasan minimun secara klasikal. Sedangkan untuk penilaian keaktifan, prosentase keaktifan siswa dalam bersikap ilmiah mencapai $85,71 \%$. Penilaian ketrampilan mencapai prosentase $82,86 \%$ dengan nilai rata-rata ketrampilan sebesar 77,14 .

Berdasarkan perolehan prosentase nilai hasil belajar dari siklus I dan siklus II mengalami peningkatan sebesar $11,42 \%$ untuk nilai pengetahuan, sedangkan keaktifan siswa meningkat sebesar $14,28 \%$, sedangkan keterampilan siswa meningkat sebesar $11,43 \%$

Perbandingan hasil prosentasi ketuntasan nilai pengetahuan secara klasikal siswa pada prasiklus,siklus I dan siklus II tampak pada grafik 1 di bawah ini.

\section{Prosentase Ketuntasan Klasikal untuk Pengetahuan}

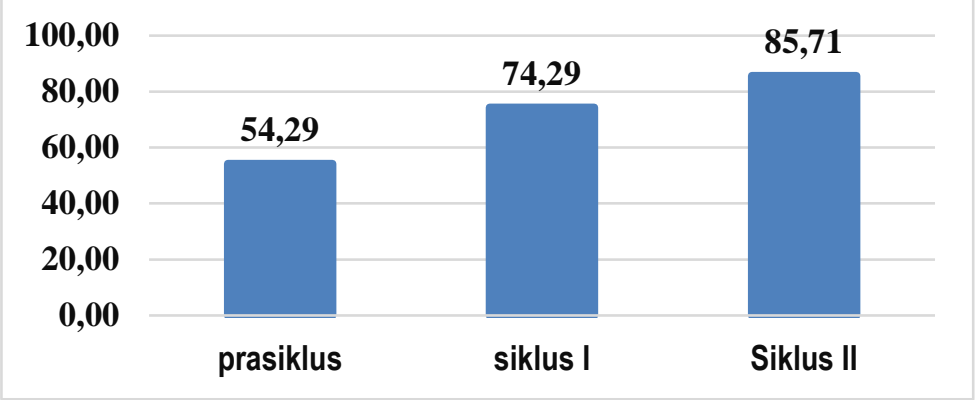

Grafik 1 Prosentase Ketuntasan pada Prasiklus,Siklus I dan Siklus II

Perbandingan nilai tes hasil belajar siswa tampak pada grafik 2 di bawah ini.

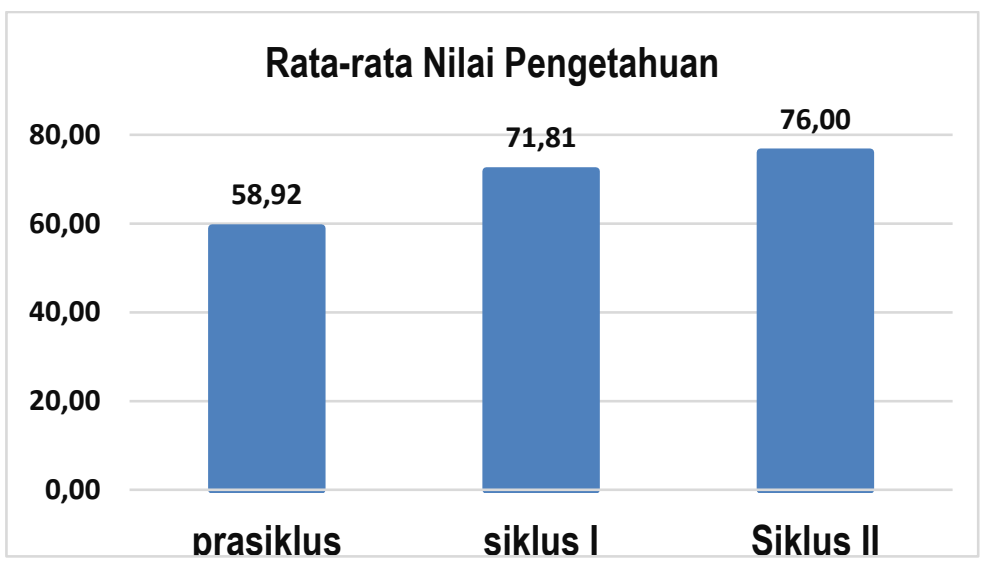

Grafik 2. Nilai Rata -Rata Tes pada Prasiklus,Siklus I dan Siklus II 
Berdasarkan grafik diatas tampak ada kenaikan rata-rata nilai siswa pada tiap siklusnya. Kenaikan dari prasiklus ke siklus I sebesar 12,89, kenaikan siklus I ke siklus II sebesar 4,14 dari nilai rata-rata 71,81 menjadi rata-rata nilainya 76,00. Hal ini mencerminkan keberhasilan siklus ke II. Perbandingan hasil tes siklus I dan siklus II untuk tiap siswa akan tampak pada grafik 3 di bawah ini.

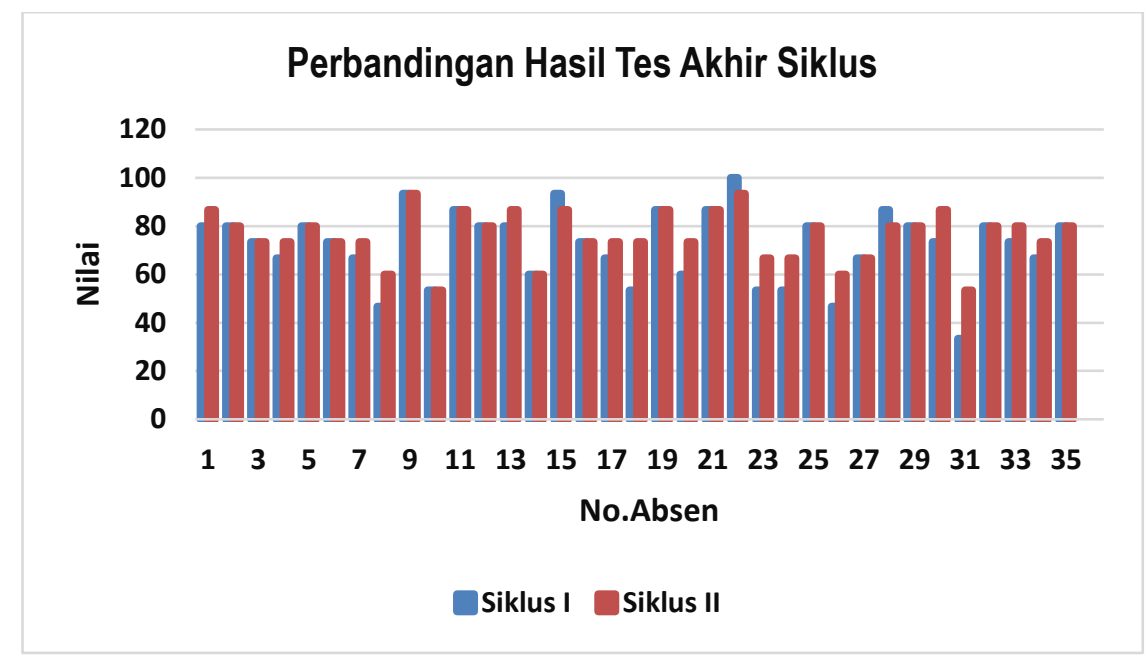

\section{Grafik 3 Hasil Tes Akhir Siklus Tiap Siswa}

Berdasarkan grafik hasil tes ketuntasan belajar siswa secara klasikal dari siklus I sebesar $74,29 \%$ meningkat sebesar $85,71 \%$ pada siklus II. Peningkatan aktivitas siswa sangat siginifikat dengan indikasi siswa lebih bersifat mandiri, tanggung jawab, disiplin dan santun. Hal ini ditunjukkan dengan kenaikan prosentase keaktifan siswa dalam sikap ilmiah yang tampak pada grafik 4 di bawah ini.

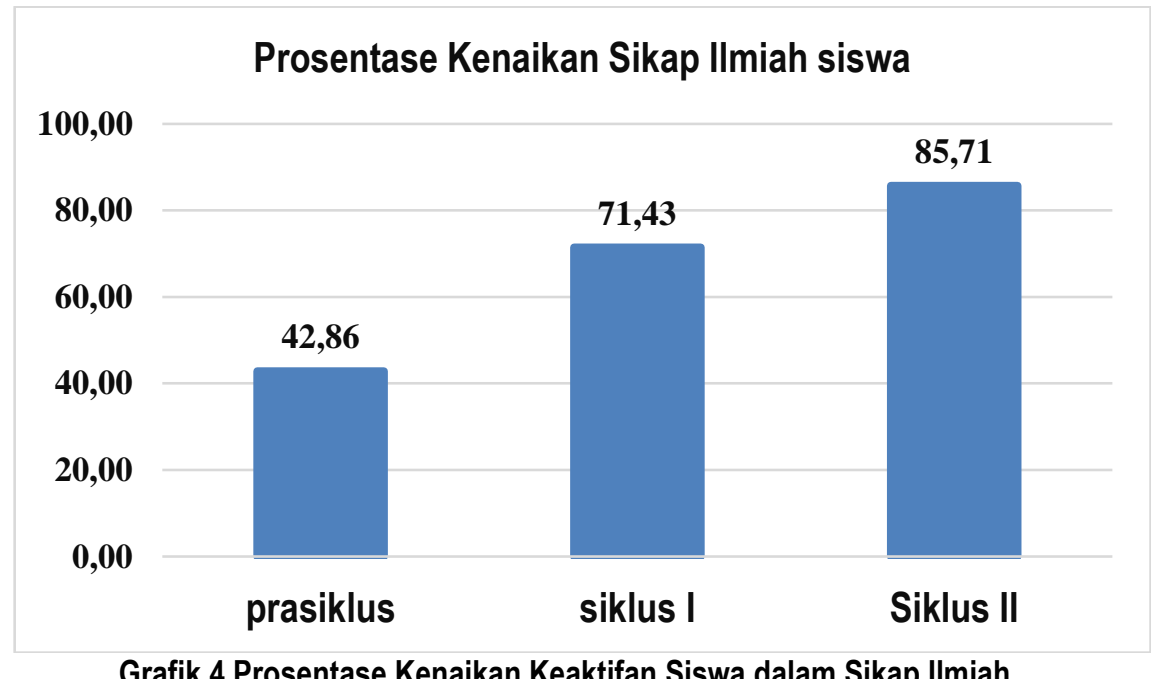

Berdasarkan grafik di atas maka prosentase kenaikan keaktifan siswa dari siklus I dan siklus II sebesar 14,28\%. Adapun kenaikan prosentasi nilai Keterampilan siswa pada tiap siklus akan tampak pada grafik 5 di bawah ini. 
Efektor, Volume 7 Issue 2, 2020, Pages 171-180

Ika Vidiasari Aristawati

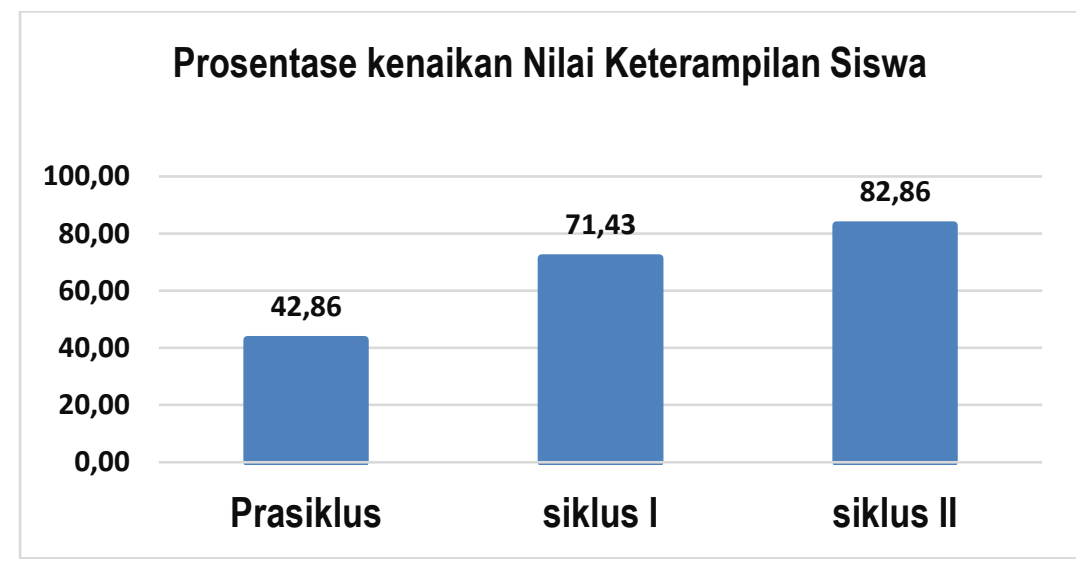

Grafik 5 Prosentase kenaikan nilai keterampilan tiap siklus.

Berdasarkan grafik di atas maka prosentase kenaikan nilai keterampilan siswa sebesar $11,43 \%$. Kenaikan prosentasi ini ditunjukkan secara nyata pada kegiatan siswa, tampak lebih antusias ketika mereka dibebaskan untuk menemukan sendiri konsep-konsep yang berkaitan dengan gerak vertikal. Berdasarkan paparan di atas, pembelajaran fisika dengan model pembelajaran Brainstorming dapat meningkatkan hasil belajar siswa pada ranah pengetahuan, sikap dan keterampilan pada siswa kelas X. Maka dari itu metode ini merupakan salah satu cara untuk meningkatkan hasil belajar siswa sehingga tujuan belajar tercapai sesuai standar ketuntasan indvidu maupun klasikal sesuai dengan pendapat yang dinyatakan (Karim, 2017, Robertus at el 2019, Asril. 2018, Ma'rufah at el 2016, Ika Eryanti. 2015).

\section{SIMPULAN}

Berdasarkan hasil penelitian dan pembahasan serta analisis yang telah dilakukan dapat disimpulkan bahwa model pembelajaran Brainstorming dapat meningkatkan ketuntasan belajar $74,29 \%$ pada siklus pertama dan mengalami peningkatan $11,42 \%$ sehingga menjadi $85,71 \%$ pada siklus kedua, keaktifan siswa dalam bersikap ilmiah mencapai $71,43 \%$ pada siklus pertama dan mengalami peningkatan $14,28 \%$ sehingga menjadi $85,71 \%$ pada siklus kedua, sedangkan ranah keterampilan $71,43 \%$ pada siklus pertama dan mengalami peningkatan $11,43 \%$ sehingga menjadi $82,86 \%$ pada siklus kedua.

Dari hasil penelitian yang diperoleh saran sebagai berikut: (1) Sekolah hendaknya memberikan pelatihan penerapan model pembelajaran untu meningkatkan kualitas pembelajaran Fisika dengan lebih baik. (2) Guru hendaknya sering melakukan penelitian tindakan kelas, dapat meningkatkan kualitas pembelajaran serta penggunaan model pembelajaran yang tepat untuk materi-materi Fisika. (3) Siswa dapat menerima dan memahami konsep fisika dengan mudah sehingga dapat meningkatkan partisipasi dan hasil belajar fisika dengan menggunakan metode pembelajaran yang tepat

\section{DAFTAR PUSTAKA}

Asril. 2018. Penerapan Strategi Belajar Peta Konsep (Concept Mapping) untuk Meningkatkan Hasil Belajar PKN Siswa Kelas IV Sekolah Dasar. Jurnal Primary Program Studi Pendidikan Guru Sekolah Dasar Fakultas Keguruan dan Ilmu Pendidikan Universitas Riau Vol 7 Nomor 1 (April 2018): 112-121

Arikunto, Suharsimi. 2019. Penelitian Tindakan Kelas, Jakarta: Bumi Aksara 
Fauzatul Ma'rufah Rohmanurmeta, Arni Gemilang Harsanti dan Heny Kusuma Widyaningrum. 2016.Pengaruh Metode Brainstorming terhadap Motivasi dan Hasil Belajar pada Pembelajaran Tematik Integratif. Jurnal Dimensi Pendidikan dan Pembelajaran Vol.4No.2 (Juli 2016): 10-20

Hamalik, Oemar. 2006. Proses Belajar Mengajar. Bandung: Bumi Aksara

Ika Eryanti. 2015. Pengaruh Strategi Belajar Peta Konsep terhadap Ketuntasan Belajar Matematika Siswa. Jurnal Pendidikan Matematika dan Matematika Vol 1, No 2 (Desember 2015): 45-58

Karim, Abdul. 2017. Penerapan Metode Brainstorming pada Mata Pelajaran IPS untuk Meningkatkan Hasil Belajar Kelas VII di SMPN 4 Rumbio Jaya. Jurnal Pendidikan Ekonomi Akuntansi FKIP UIR Vol 5 No 1 (2017):1-12

Wardani, Nyoman Tri. 2016. Penerapan Metode Brainstorming dalam Rangka Peningkatan Aktivitas dan Hasil Belajar pada Mata Pelajaran Ekonomi siswa Kelas XI IPS 1 SMA Negeri 1 Sukasada Tahun Ajaran 2016/2017. Jurnal Program Studi Pendidikan Ekonomi Vol 8 No. 3 (2016): 1 10

Palil, Nafik. 2018. Sekolah tanpa PR 4 Model Pembelajaran. Surabaya: Madril Pustaka Production

Robertus Febrima Yulianto, Syaiful M, Muhammad Basri. 2019. Pengaruh Penerapan Metode Pembelajaran Brainstorming terhadap Hasil Belajar Sejarah Siswa Kelas X-1. Jurnal Pendidikan dan Penelitian Sejarah Vol 07 No. 01 (2019): 1-12

Taniredja, Dkk. 2010. Penelitian Tindakan Kelas. Bandung: Alfabeta 